\title{
Islamic Capital Market Reaction on Presidential Election 2019 (Case Study on the Jakarta Islamic Index)
}

\author{
Syintia Dwi Utami ${ }^{1}$, Abdul Qoyum ${ }^{2 *}$ \\ ${ }^{1,2}$ Faculty of Islamic Economics and Business, State Islamic University \\ Sunan Kalijaga, Yogyakarta, Indonesia \\ *qoyum13@gmail.com
}

Article History

\begin{tabular}{lll}
\hline Received & $: 2020-08-12$ \\
\hline Revised & $: 2020-11-14$ \\
\hline Accepted & $:$ & $2020-12-08$ \\
\hline
\end{tabular}

\section{Abstract}

Introduction to The Problem: General Election (GE) is one of the most important political issues which has an impact on the economic condition.

Purpose/Objective Study: This research aims to reveal the effect of General Election 2019 on the capital market reaction. Specifically, the study compares the impact of three events in the GE 2019, namely, The General Election 2019, the announcement of Elected President 2019, and Mahkamah Konstitusi (MK) decision.

Design/Methodology/Approach: The samples of the study are the 30 firms listed in Jakarta Islamic Index. The study was employing Abnormal Return with t-test analysis.

Findings: The study reveals that the publication of the elected-president has the most significant impact on the Islamic Capital Market compares to the two other events. While using Trading Volume Activity (TVA), all the three events of GE 2019 affects the TVA. This finding suggests that for the Islamic capital market investor, the announcement of the elected president is seen as the most significant event that determines the whole of economic condition for the next five years. Hence, for the policy-makers, they must focus on the date of the announcement by preparing such a policy to maintain the market condition.

Paper Type: Research Article

Keywords: Abnormal Return; Event Study; General Election 2019; Jakarta Islamic Index; Trading Volume Activity.

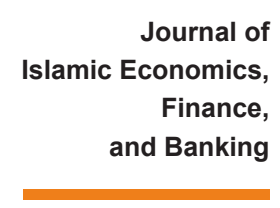

Vol. 3, No. 2, December 2020 , pp. 105-124, ISSN p:2622-4755 e:2622-4798

然

喝

IHTIFAZ

UNIVERSITAS AHMAD DAHLAN

Kampus 4

Kampus 4
Universitas Ahmad Dahlan Universitas Ahmad Dahlan
I. Ringroad Selatan, Tamanan Banguntapan, Bantul Yogyakarta 55191 e-mail : ihtifaz@uad.ac.id 


\section{INTRODUCTION}

A capital market is a place where long-term financial instruments are IHTIFAZ - JIEFB traded, such as stocks, bonds, warrants, and various derivative products (Darmadji, 2001). According to Tecualu and Megge (2009), the stock price can be influenced by several factors, such as internal factors and external factors. Internal factors are factors that can be controlled by the company, including, among others, company performance, changes in corporate strategy, mergers, announcements of financial statements or company dividends, etc. Meanwhile, external factors come from environmental influences beyond the company's control, such as the economic and political conditions of a country (Qoyum et al., 2020).

According to Suryawijaya, et al. (1998), the more critical the role of the stock exchange in economic activity, the more sensitive of the stock market to such events, whether the events are directly or indirectly related to these economic events. The reactions to these events can be tested for the information content. According to Jogiyanto (1998), examining the information content is intended to see the response of the market. If the announcement contains information, it is expected that the market will react when the announcement is received by the market, which can be seen from the abnormal return and trading volume activity. One of the political events that have an impact on the Islamic capital market is General Election.

One of Indonesia's political conditions that occurs regularly and greatly affects economic stability is the presidential election, which is held every five years. On 9 July 2014, a presidential election was held in Indonesia. This event caused index movement both before and after the election was held. According to Sook Mei Leong, head of global market research at MUFG Bank Ltd, Indonesian stocks had rallied six months before and after each general the direct presidential election, with the most significant increase when the system was first used in 2004 (Bloomberg, 2019). Several months ago, on 17 April 2019, Indonesia held simultaneous general elections for the legislative and executive. In this political year, many events really caught the attention of the state and investors. For example, there are differences in the calculation of the quick election count, the rejection of the KPU's decision until a lawsuit is filed at the Constitutional Court. Reporting from CCN Indonesia, the international rating agency Moody's Investor Service said the results of quick counts conducted by several survey institutions supported investment and the stability of Indonesia's economic growth, which would also have an impact on the financial market stability.

Besides, the Ministry of Industry believes that the industrial growth rate and business climate are improving. This is marked by the good market response, as shown by the JCI, which has consistently strengthened since the beginning of trading (Ipotnews, 2019). Finally, after a lawsuit was filed with the Constitutional Court regarding the 2019 
Election decision, the decision submitted was considered to provide certainty for investors. The Director of Panin Asset Management stated that in the short term, this sentiment brought good conditions for the JCI (Kontan.co.id, 2019).

Many previous researches on event studies has been conducted to investigate the reaction of the capital market to such an event. Pp. 105-124, ISSN p:2622-4755 Apart from events related to the fundamentals of a company, event studies are also often used to examine capital market reactions to events outside of economic events, such as political events. Manurung and Ira K. (2005) conducted research on several political events such as the announcement of the results of the legislative elections, the announcement of the results of the presidential election, announcements of cabinet composition, cabinet reshuffles on abnormal returns in the industrial sector on the Jakarta Stock Exchange which showed that there was no significant abnormal difference.

Ardiansyah and Qoyum (2011) have studied event study research for the Islamic capital market by examining the semi-strong market efficiency theory on dividend announcements in the Jakarta Islamic Index. The study revealed that the Islamic capital market, which in this study uses JII is not efficient in the information (Revelli, 2017). This means that the stock price that occurs cannot reflect a strong relationship with the real conditions that exist within the company. The magnitude of the abnormal return indicates that the market still has symptoms of asymmetric information (Sairally, 2013).

The study is different from previous research from two points of view. First, the study will examine the impact of the 2019 General Election on the Islamic capital market with the events used in the series of 2019 General Elections. Not only on election day, but this research also uses the delivery of election results by the KPU and the MK decisions as observed events. Second, this study aims to find which event has the largest information content in the 2019 General Election series.

\section{THEORETICAL AND LITERATURE REVIEW}

\section{Political Risk and The Efficient Market Hypothesis}

According to Bailey (1995), political risk is a political action taken by the government or carried out by the people of a country which can affect the economic condition. Investors and companies need to mitigate political risk. Thus, they can formulate the right strategy in dealing with it so that this risk can be an opportunity that can be maximized. The political event also assumed has a strong relationship with the abnormal return of the capital market. If the market is efficient, the price movement is fully reflecting the information (Rizaldy \& Ahmed 2019).

The concept of an efficient market was first proposed by Fama (1970). A market is said to be efficient if no one, either individual 
investors or institutional investors, can obtain an abnormal return, after adjusting for risk, using existing trading strategies. Thus, the prices formed in the market are a reflection of existing information, or "stock prices reflect all available information." Another expression states that in an efficient market, the prices of assets or securities quickly and completely reflect the available information about these assets or securities (OJK, 2016).

According to Fama (1970), the efficient form of the market can be classified into three, namely weak-form market efficiency, semi-strong form market efficiency, and strong form market efficiency. A strong form of market efficiency describes in which the prices of securities fully reflect past information (Renneboog et al., 2008). In this form, past information cannot be used to predict current prices. So, investors cannot use past information to get abnormal returns (Hartono, 2017).

Semi-strong market efficiency describes a market in which the prices of securities fully reflect all published information. No investor can use published information to get abnormal returns for a long period of time (Hartono, 2017). Finally, the form of market efficiency describes a market in which the prices of securities fully reflect all information, including private information. There are no investors who can get an abnormal return because they have private information (Hartono, 2017).

\section{Event Study and Abnormal Return}

An event study is also called a residual analysis or an abnormal performance index test or a market reaction test. Bowman (1983) defines an event study as a study that involves analyzing the price behavior of security around the time of an event or information announcement. Event studies examine the reaction of a market to an event (Sadeghi, 2008). The market reaction can be proxied in the abnormal return and trading volume activity. According to Hartono (2010), abnormal return or excess return is the value more than the actual return, expected by investors (expected return). In other words, abnormal return is the difference between the actual return and the expected return with the equation:

$$
R T N_{i, t}=R_{i, t}-E\left(R_{i, t}\right)
$$

Where, $R T N_{i, t}$ is the abnormal return, $R_{i, t}$ is the actual return, and $E\left(R_{i, t}\right)$ is the expected return. While according to Rumanti and Moerdiyanto (2012), trading volume activity is the ratio between the number of shares traded in a certain period and the number of outstanding shares of the company in a certain period. Trading volume activity (TVA) is an indicator that can be used to measure the capital market reaction to information or events that occur in the capital market by using stock trading volume activity as a parameter (Napitupulu dah Syahyunan, 2014). Trading volume activity is calculated by comparing 
the number of traded shares in a certain period, with the total number of outstanding shares in that period.

$$
T V A=\frac{\text { the number of traded shares }}{t}
$$

\section{Jakarta Islamic Index}

Vol. 3, No. 2, December 2020, pp. 105-124, ISSN p:2622-4755

The capital market can formally be defined as a place for buying and selling various long-term financial instruments (or securities), which can be in the form of debt or equity, whether issued by public authority companies, private companies, or the government (Husnan, 2005). The Islamic capital market can be said to be a capital market that applies sharia principles. Therefore, the traded instruments must not contradict Islamic law, such as usury (interest), gambling, speculation, food, and beverage producers that are prohibited in Islam. One of the Islamic capital market indexes is the Jakarta Islamic Index (JII).

The Jakarta Islamic Index (JII) consists of 30 types of stocks selected from stocks that comply with the Islamic principle, which are evaluated every six months. Determination of the components of the index every January and July (Tanjung \& Martua Siregar, 2018; Widodo, 2017). Meanwhile, changes in the issuer's type of business will be continuously monitored based on publicly available data. The calculation of the Jakarta Islamic Index (JII) is carried out by the Indonesia Stock Exchange (IDX) using the index calculation method established by the Indonesia Stock Exchange (IDX), namely by market capitalization weight (market cap-weighted). This index calculation also includes adjustments due to changes in the issuer's data due to corporate actions (Setyowati \& Ningsih, 2016).

\section{HYPOTHESIS}

This study has the following hypotheses:

1. There is a difference in the average abnormal return before, after, and during the 2019 Election series, which includes the 2019 general election, the announcement of the 2019 General Election results by the KPU, the announcement of the Constitutional Court's decision on the 2019 General Election lawsuit on company shares registered in JII.

2. There is a difference in the average trading volume before, after, and during the 2019 Election series, which includes the 2019 general election, the announcement of the 2019 General Election results by the KPU, the announcement of the Constitutional Court's decision on the 2019 General Election lawsuit on stocks companies registered in JII. 


\section{METHODOLOGY}

IHTIFAZ - JIEFB

\section{Sample and Sources of Data}

The population in this study were all companies listed in the Islamic capital market. The criteria for stocks that will be used as research samples are stocks that meet the criteria of sharia, have the largest market capitalization and have a high level of trading value liquidity and stocks that are listed on the Jakarta Islamic Index around the April - June 2019 event period. 27 securities companies were selected that consistently remain listed on the list of JII. This research will use an event study approach as a research method. Event studies examine the reaction of a market due to an event (Hartono, 2010). Sources of data in this study are quantitative data obtained from yahoo finance, OJK, and BEI.

\section{Abnormal Return}

This study used 15 days of observation, namely 7 days before the event and 7 days after the event, with the event day as event day (t0). The observation period with a shorter period is expected to capture the effect of a more significant event. The abnormal return calculation begins with calculating the actual return. The actual return or actual return can be calculated using the difference between the current price and the price of the previous period. The price used is the closing price or closed price of the security in the event period.

$$
\text { Return }=\frac{P_{t}-P_{t-1}}{P_{t-1}}
$$

Like the calculation of actual return, the difference between the current index price and the index price in the past period is also used to calculate market returns. The market return used is the return from the Jakarta Islamist Index (JII).

$$
\text { Return Pasar }=\frac{J I I_{t}-J I I_{t-1}}{J I I_{t-1}}
$$

This study uses the Market-adjusted model as a model for calculating the expected return. This model assumes that the market index return at that time is the best predictor for estimating the return of a security.

$$
E\left(R_{i, t}\right)=R_{M, t}
$$

Abnormal return or abnormal return is the difference between the actual return and the expected return with the equation:

$$
R T N_{i, t}=R_{i, t}-E\left(R_{i, t}\right)
$$

Tests for abnormal returns are carried out in an aggregated manner by examining the average cross-sectional return of all securities every day during the event period. 


$$
\operatorname{RRTN}_{t}=\frac{\sum_{i=1}^{N} R T N_{i, t}}{N}
$$

\section{Accounting Trading Volume Activity}

Trading volume activity is calculated by comparing the number of shares traded in a certain period, with the total number of shares outstanding in that period.

$$
T V A=\frac{\text { the number of traded } \text { shares }_{t}}{\text { the total number of outstanding shares }}
$$

The average TVA can be calculated by:

$$
X T V A_{t}=\frac{\sum_{i=1}^{N} T V A_{i, t}}{N}
$$

\section{RESULTS AND DISCUSSION}

\section{Descriptive Statistics}

Table 1 compares the abnormal returns of the three events studied. From this table, it can be seen that the lowest abnormal return value is in the second event, namely the announcement of the result of the General Election 2019 by KPU, with a value of -0.02626 . Likewise, the maximum abnormal return value exists in the second event, with a value of 0.02479 . Table 1 also shows that the highest abnormal return value occurred in the first event, namely the Presidential Election 2019.

Table 1. Descriptive of Abnormal Return

\begin{tabular}{lrrrrr}
\hline & N & Minimum & Maximum & Mean & \multicolumn{1}{l}{ Std. Deviation } \\
\hline GE 2019 & 15 &,- 01872 &, 01874 &, 0006193 &, 01094930 \\
GE 2109 Result & 15 &,- 02626 &, 02479 &, 0000000 &, 01528305 \\
MK Result & 15 &,- 01275 &, 01668 &, 0000081 &, 00898422 \\
Valid N (listwise) & 15 & & & & \\
\hline
\end{tabular}

Source: Data Processed, 2020

The comparison in terms of the descriptive trading volume activity test shows that the lowest trading volume value is in the third event or the announcement of the Constitutional Court's decision on the 2019 General Election lawsuit with a value of 0.00107. Meanwhile, the highest trading volume activity value was found in the second event, i.e., the announcement of the results of the 2019 General Election by the KPU, with a value of 0.00253 . Besides, the event of the announcement of the 2019 General Election results by the KPU has a higher an average value of trading volume activity than the other two events with a value of 0.0020525 . 
Table 2. Descriptive of Trading Volume Activity

\begin{tabular}{lrrrrr}
\hline & N & Minimum & Maximum & \multicolumn{1}{l}{ Mean } & Std. Deviation \\
\hline GE 2019 & 15 &, 00115 &, 00354 &, 0018320 &, 00057805 \\
GE 2109 Result & 15 &, 00113 &, 00565 &, 0020525 &, 00105006 \\
MK Result & 15 &, 00107 &, 00253 &, 0017916 &, 00043734 \\
Valid N (listwise) & 15 & & & & \\
\hline
\end{tabular}

Sources: Data processed, 2020

Therefore, the finding can be concluded that based on the descriptive data evidenced that the announcement of general election 2019 result containt more information comppared to the other events. At the time of the event, investors get the highest and smallest returns, and their stock trading activities have the highest value both daily and also its average in the window period.

\section{Abnormal Return}

Hypothesis testing is conducted by performing One-sample t-test calculations using IBM SPSS Statistics 24. Besides, the test was also carried out by descriptive analysis in analyzing the graph of the movements that occurred during the research observation period.

Table 3. T-Test of Abnormal Return General Election 2019

\begin{tabular}{cccccc}
\hline & T & Df & Sig. (2-tailed) & Result & $\begin{array}{c}\text { Average } \\
\text { Abnormal Return }\end{array}$ \\
\hline H-7 & $-3,423$ & 26 &, 002 & Significant & $-0,01208$ \\
H-6 & 7,563 & 26 &, 000 & Significant & 0,01874 \\
H-5 &,- 848 & 26 &, 404 & Not Significant & $-0,00293$ \\
H-4 & $-1,396$ & 26 &, 175 & Not Significant & $-0,00531$ \\
H-3 & $-1,186$ & 26 &, 246 & Not Significant & $-0,00510$ \\
H-2 &, 455 & 26 &, 653 & Not Significant & 0,00142 \\
H-1 & 2,554 & 26 &, 017 & Significant & 0,00929 \\
H+1 & 1,278 & 26 &, 213 & Not Significant & 0,00342 \\
H+2 & $-3,208$ & 26 &, 004 & Significant & $-0,01287$ \\
H+3 & 6,478 & 26 &, 000 & Significant & 0,01741 \\
H+4 & $-1,373$ & 26 &, 181 & Not Significant & $-0,00492$ \\
H+5 & $-5,160$ & 26 &, 000 & Significant & $-0,01872$ \\
H+6 & 3,019 & 26 &, 006 & Significant & 0,00946 \\
H+7 &, 670 & 26 &, 508 & Not Significant & 0,00219 \\
\hline
\end{tabular}

Sources: Data processed, 2020

Table 3 describes the t-tes results of the daily abnormal return before and after the 2019 General Election, or in 17 April, 2019. From this table, it can be seen that for the 7 days before the 2019 General Election, three days of significant value were registered, namely h-7, h. -6 , and h-1 
with an average abnormal return of $-0.01208,-0.00293$, and 0.00929 , respectively. Whereas for 7 days after the 2019 General Election, there were four days of significant value, namely $h+2, h+3, h+5$, and $h+6$ with an average abnormal return of $-0.01287,0.01741,-0.01872$, and 0.00946 . In addition, it can also be seen that the maximum abnormal return is at $h+6$ and $h+3$, with a value of 0.01874 and 0.01741 .

Moreover, the result also reveals there is no difference in the average

Journal of Islamic Economics, Finance, and Banking

Vol. 3, No. 2, December 2020, pp. 105-124, ISSN p:2622-4755 e:2622-4798 abnormal return before and after the 2019 General Election. Therefore, the hypothesis stateed that "there is a difference in the average abnormal return in the period of before and after the 2019 Election event" was rejected. The movement of changes in daily abnormal returns indicates that even though the market responds to the events of the 2019 General Election series, there is no significant effect on the level of profits obtained by shareholders in the Islamic capital market.

Table 4. T-Test of Abnormal Return in the Announcement of GE 2019 Result by KPU

\begin{tabular}{cccccc}
\hline & T & Df & Sig. (2-tailed) & Result & $\begin{array}{c}\text { Average } \\
\text { Abnormal Return }\end{array}$ \\
\hline H-7 &,- 489 & 26 &, 629 & Not Significant & $-0,00134$ \\
H-6 & $-5,562$ & 26 &, 000 & Significant & $-0,02596$ \\
H-5 &, 305 & 26 &, 762 & Not Significant & 0,00107 \\
H-4 & $-7,054$ & 26 &, 000 & Significant & $-0,02626$ \\
H-3 & $-2,102$ & 26 &, 045 & Significant & $-0,00595$ \\
H-2 & $-2,057$ & 26 &, 050 & Significant & $-0,00953$ \\
H-1 & 5,030 & 26 &, 000 & Significant & 0,02055 \\
H0 & 3,202 & 26 &, 004 & Significant & 0,01438 \\
H+1 &,- 389 & 26 &, 701 & Not Significant & $-0,00088$ \\
H+2 & 7,674 & 26 &, 000 & Significant & 0,02479 \\
H+3 & $-5,256$ & 26 &, 000 & Significant & $-0,01254$ \\
H+4 & 2,947 & 26 &, 007 & Significant & 0,00866 \\
H+5 & $-1,224$ & 26 &, 232 & Not Significant & $-0,00676$ \\
H+6 & 1,050 & 26 &, 303 & Not Significant & 0,00444 \\
H+7 & 3,320 & 26 &, 003 & Significant & 0,01533 \\
\hline
\end{tabular}

Sources: Data processed, 2020

While for Table 4. shows the results of the daily abnormal return test before and after the announcement of the 2019 general election result by the KPU on 21 May 2019. The table shows that the value of abnormal return from $\mathrm{H}-4$ until $\mathrm{HO}$ of the announcement of the 2019 general election results, by the KPU, are $-0.02626,-0.00595,-0.00953$, 0.02055 and 0.01438 . Although one day after the event was not significant, there is four days after the announcement was statistically significant, with the mean abnormal return values $0.02479,-0.01254$, and 0.00866 , respectively. In addition, maximum abnormal returns were found at $h-1$ and $h+2$ with a value of 0.02479 and 0.02055 . 
From the t-test calculation above, it can be seen that there is statistical difference of the average abnormal return on the announcement of the 2019 general election results by the KPU. Therefore, the hypothesis which states "there is a difference in the average abnormal return in the period before and after the event of the announcement of the results of the 2019 general election by the KPU" is accepted. The movement of changes in abnormal returns on a daily basis indicates that the market responds to the announcement of the 2019 general election result announcement by the KPU.

Table 5. T-Test of Abnormal Return of Mahkamah Konstitusi Decision

\begin{tabular}{cccccc}
\hline & T & Df & $\begin{array}{c}\text { Sig. } \\
\text { (2-tailed) }\end{array}$ & Result & $\begin{array}{c}\text { Average } \\
\text { Abnormal Return }\end{array}$ \\
\hline H-7 & 1,771 & 26 &, 088 & Not Significant & 0,00787698 \\
H-6 & 3,530 & 26 &, 002 & Significant & 0,01062338 \\
H-5 &,- 551 & 26 &, 587 & Not Significant & $-0,00213204$ \\
H-4 &,- 826 & 26 &, 416 & Not Significant & $-0,00276707$ \\
H-3 & $-3,762$ & 26 &, 001 & Significant & $-0,00959730$ \\
H-2 & 1,799 & 26 &, 084 & Not Significant & 0,01667842 \\
H-1 & 1,000 & 26 &, 326 & Not Significant & 0,00277658 \\
H-0 & 3,675 & 26 &, 001 & Significant & 0,01232970 \\
H+1 & $-4,367$ & 26 &, 000 & Significant & $-0,01184637$ \\
H+2 &, 846 & 26 &, 405 & Not Significant & 0,00290940 \\
H+3 &, 227 & 26 &, 822 & Not Significant & 0,00095071 \\
H+4 & $-4,053$ & 26 &, 000 & Significant & $-0,01274619$ \\
H+5 &,- 635 & 26 &, 531 & Not Significant & $-0,00170960$ \\
H+6 &,- 984 & 26 &, 334 & Not Significant & $-0,00433674$ \\
H+7 & $-2,567$ & 26 &, 016 & Significant & $-0,00888891$ \\
\hline
\end{tabular}

Sources: Data processed, 2020

The table 5 shows the results of the daily abnormal return test, before and after the announcement of the Constitutional Court's decision on the 2019 General Election lawsuit on 27 June, 2019. The third day before the announcement shows significant abnormal return of with a significance value of -0.00959730 . Significant results were also found on the day of the announcement, and the one day after, with significance values at 0.01232970 and -0.01184637 , respectively. After 
that, significant results are found at $\mathrm{h}+4$ and $\mathrm{h}+7$ with -0.01274619 and -0.00888891 , respectively.

From the calculation of the t-test above, it can be seen that there is a difference in the average abnormal return before and after the announcement of the Constitutional Court decision on the 2019 General Election lawsuit. Therefore, the hypothesis states "there is a difference in the average abnormal return in the period before and after the incident the announcement of the Constitutional Court decision on the 2019 General Election lawsuit" was rejected. The movement of changes in daily abnormal returns indicates that, even though the market responds to the events of the 2019 General Election series, there is no significant effect on the level of profits obtained by shareholders in the Islamic capital market.

Figure 1. Abnormal Return

\section{Abnormal Return}

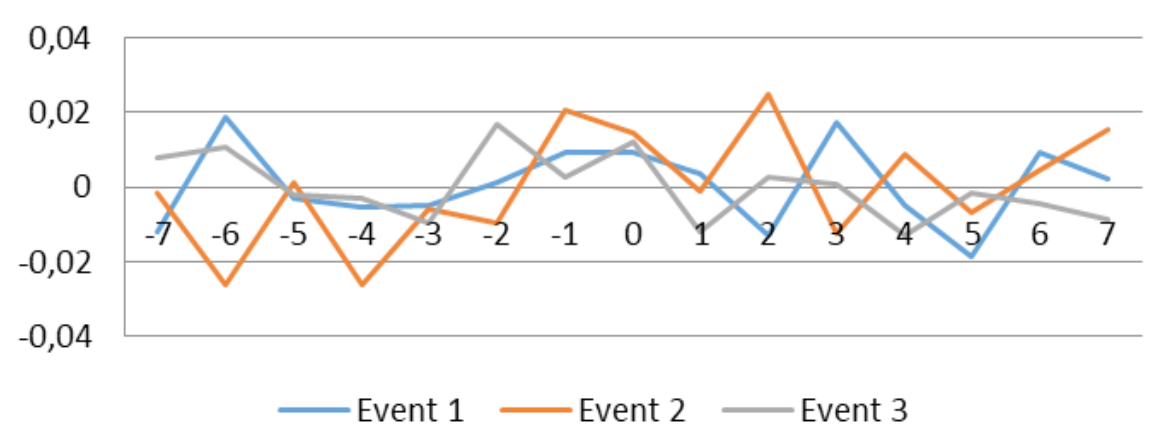

Sources: Data processed, 2020

From the analysis of the abnormal return chart above, it can be seen carefully that the movement of the abnormal return graph is very fluctuating in all events. Significant graphical movements were found in the second event, the announcement of the 2019 General Election results by the KPU. This can be seen from the drastic increases in abnormal returns both before and after the general election day. In addition, with regard to the maximum and minimum values, from this graph it is clear that the announcement of the 2019 General Election results by the KPU has a maximum value higher than the other two events, namely at $h+2$ and the lowest value in the day $h-6$ and $h-4$.

Based on the tests that have been carried out, only the second event, namely the announcement of the 2019 general election results by the KPU, has a difference in the average abnormal return. Thus, it can be concluded that only the second event was successful in showing a significant influence between the stock return variable and the events of the 2019 General Election series. 


\section{Analyze of Trading Volume Activity}

The table 6 shows the One-samples Test of the daily trading volume IHTIFAZ - JIEFB activity before and after the 2019 General Election on 17 April, 2019. From this table it can be seen that during the research period, the different of TVA value was significant, because it had a value of less than $5 \%$. In addition, it can also be seen that the highest TVA value for this event is on the first day after the 2019 Election $(h+1)$ with a TVA value at 0.00354 . Meanwhile, the lowest stock trading activity occurred on the 4th day with a TVA value at 0.00115 .

Table 6. T-Test of Trading Volume Activity General Election 2019

\begin{tabular}{cccccc}
\hline & $\mathrm{t}$ & $\mathrm{df}$ & Sig. (2-tailed) & Result & $\begin{array}{c}\text { Average Trading } \\
\text { Volume Activity }\end{array}$ \\
\hline $\mathrm{H}-7$ & 4,342 & 26 &, 000 & Significant & 0,00155 \\
$\mathrm{H}-6$ & 5,191 & 26 &, 000 & Significant & 0,00149 \\
$\mathrm{H}-5$ & 3,976 & 26 &, 000 & Significant & 0,00145 \\
$\mathrm{H}-4$ & 4,024 & 26 &, 000 & Significant & 0,00115 \\
$\mathrm{H}-3$ & 3,768 & 26 &, 001 & Significant & 0,00129 \\
$\mathrm{H}-2$ & 4,301 & 26 &, 000 & Significant & 0,00196 \\
$\mathrm{H}-1$ & 4,111 & 26 &, 000 & Significant & 0,00235 \\
$\mathrm{H}+1$ & 4,129 & 26 &, 000 & Significant & 0,00354 \\
$\mathrm{H}+2$ & 5,109 & 26 &, 000 & Significant & 0,00162 \\
$\mathrm{H}+3$ & 4,575 & 26 &, 000 & Significant & 0,00172 \\
$\mathrm{H}+4$ & 4,362 & 26 &, 000 & Significant & 0,00174 \\
$\mathrm{H}+5$ & 5,404 & 26 &, 000 & Significant & 0,00184 \\
$\mathrm{H}+6$ & 3,772 & 26 &, 001 & Significant & 0,00167 \\
$\mathrm{H}+7$ & 3,875 & 26 &, 001 & Significant & 0,00176 \\
\hline
\end{tabular}

Sources: Data processed, 2020

From the calculation of the t-test above, it can be seen that there is a difference in the average abnormal return before and after the 2019 General Election. Therefore, the hypothesis states "There is a difference in the average trading volume activity in the period before and after the 2019 Election" was accepted.

The One-samples Test table above shows the results of the daily trading volume activity test before and after the announcement of the 2019 General Election results by the KPU on 21 May, 2019. From the research period, there is one day which has a significance value, namely at $h+5$ with a significance value of 0.104 . $H+5$ is also the highest TVA value during the study period, with an average trading volume value of 0.00565 . In contrast, the lowest value is found at $h+1$ with a TVA value of 0.00113 . 
Table 7. T-Test Trading Volume Activity Announcment of General Election 2019 Result by KPU

Journal of

\begin{tabular}{|c|c|c|c|c|c|c|}
\hline & $\mathrm{T}$ & Df & $\begin{array}{c}\text { Sig. } \\
\text { (2-tailed) }\end{array}$ & Result & $\begin{array}{l}\text { Average Trading } \\
\text { Volume Activity }\end{array}$ & \\
\hline $\mathrm{H}-7$ & 6,476 & 26 & ,000 & Significant & 0,00177 & $\begin{array}{r}-124, \text { ISSN p p:2622-4/55 } \\
\text { e:2622-4798 }\end{array}$ \\
\hline $\mathrm{H}-6$ & 5,287 & 26 & ,000 & Significant & 0,00164 & \\
\hline $\mathrm{H}-5$ & 3,378 & 26 & ,002 & Significant & 0,00253 & \\
\hline $\mathrm{H}-4$ & 4,211 & 26 & ,000 & Significant & 0,00211 & \\
\hline $\mathrm{H}-3$ & 5,487 & 26 &, 000 & Significant & 0,00171 & \\
\hline $\mathrm{H}-2$ & 3,434 & 26 & ,002 & Significant & 0,00195 & \\
\hline $\mathrm{H}-1$ & 4,449 & 26 &, 000 & Significant & 0,00162 & \\
\hline $\mathrm{H}-\mathrm{O}$ & 5,657 & 26 & ,000 & Significant & 0,00181 & \\
\hline $\mathrm{H}+1$ & 2,674 & 26 & ,013 & Significant & 0,00113 & \\
\hline $\mathrm{H}+2$ & 3,945 & 26 & ,001 & Significant & 0,00197 & \\
\hline $\mathrm{H}+3$ & 5,043 & 26 & ,000 & Significant & 0,00140 & \\
\hline $\mathrm{H}+4$ & 4,215 & 26 & ,000 & Significant & 0,00155 & \\
\hline $\mathrm{H}+5$ & 1,687 & 26 & 104 & Not Signifycant & 0,00565 & \\
\hline $\mathrm{H}+6$ & 3,282 & 26 & ,003 & Significant & 0,00179 & \\
\hline $\mathrm{H}+7$ & 3,772 & 26 & ,001 & Significant & 0,00219 & \\
\hline
\end{tabular}

Sources: Data processed, 2020

From the calculation of the t-test above, it can be seen that there is a difference in the average abnormal return before and after the announcement of the results of the 2019 General Election by the KPU. Therefore, the hypothesis states "There is a difference in the average trading volume activity in the period before and after the announcement of the results of the 2019 General Election by the KPU" is accepted.

Table 8. T-Test Trading Volume Activity Announcement of Mahkamah Konstitusi

\begin{tabular}{ccccccc}
\hline & T & df & $\begin{array}{c}\text { Sig. } \\
\text { (2-tailed) }\end{array}$ & Result & $\begin{array}{c}\text { Average Trading } \\
\text { Volume Activity }\end{array}$ \\
\hline $\mathrm{H}-7$ & 5,368 & 26 &, 000 & Significant & 0,00156 \\
$\mathrm{H}-6$ & 5,209 & 26 &, 000 & Significant & 0,00187 \\
$\mathrm{H}-5$ & 4,945 & 26 &, 000 & Significant & 0,00219 \\
$\mathrm{H}-4$ & 7,492 & 26 &, 000 & Significant & 0,00198 \\
$\mathrm{H}-3$ & 5,180 & 26 &, 000 & Significant & 0,00107
\end{tabular}




\begin{tabular}{lllllll}
\hline \multirow{4}{*}{ IHTIFAZ - JIEFB } & $\mathrm{H}-2$ & 3,373 & 26 &, 002 & Significant & 0,00253 \\
& $\mathrm{H}-1$ & 2,946 & 26 &, 007 & Significant & 0,00253 \\
& $\mathrm{H}-0$ & 5,069 & 26 &, 000 & Significant & 0,00199 \\
& $\mathrm{H}+1$ & 5,461 & 26 &, 000 & Significant & 0,00166 \\
& $\mathrm{H}+2$ & 4,607 & 26 &, 000 & Significant & 0,00211 \\
& $\mathrm{H}+3$ & 5,269 & 26 &, 000 & Significant & 0,00178 \\
& $\mathrm{H}+4$ & 5,847 & 26 &, 000 & Significant & 0,00143 \\
& $\mathrm{H}+5$ & 4,206 & 26 &, 000 & Significant & 0,00150 \\
& $\mathrm{H}+6$ & 3,857 & 26 &, 001 & Significant & 0,00144 \\
$\mathrm{H}+7$ & 4,939 & 26 &, 000 & Significant & 0,00123 \\
\hline
\end{tabular}

Sources: Data processed, 2020

The table above shows the results of the One-samples test daily trading volume activity for before and after the announcement of the Constitutional Court decision on the 2019 General Election lawsuit on June 27, 2019. From this table it can be seen that during the research period the TVA value was significant because it had a value less than $5 \%$. In addition, it can also be seen that the highest TVA value for this event was on the first and second day before the announcement of the MK ( $h-1$ and $h-2$ ) with a TVA value of 0.00253 . Meanwhile, the lowest stock trading activity occurred on the 3rd day of implementation with a TVA value of 0.00107 .

From the t-test calculation above, it can be seen that there is a difference in the average abnormal return before and after the announcement of the Constitutional Court decision on the 2019 General Election lawsuit. Therefore, the hypothesis states, "There is a difference in the average trading volume activity in the period before and after the announcement of the Constitutional Court decision on the 2019 General Election lawsuit " was accepted.

The event of the announcement of the results of the 2019 General Election by the KPU shows that trading volume activity is different from the other two events even though all three fluctuate during the window period. This difference is seen from the large volume of stock trading activity at $h+5$, which indirectly makes the second event a larger average trading volume.

Based on the tests that have been done, it can be concluded that all events in the 2019 General Election series have differences in average trading volume before and after their implementation. Thus, it can be concluded that the whole event succeeded in showing a significant influence between the variable volume of stock trading activities and the events of the 2019 General Election in the Islamic capital market. 


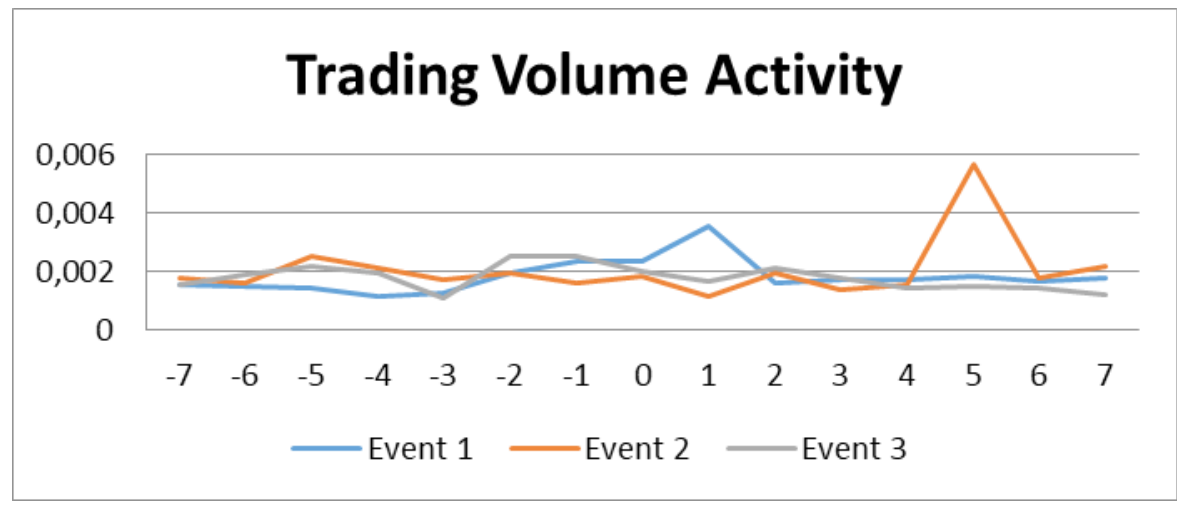

Sources: Data processed, 2020

\section{Analyze of One-way ANOVA}

The one-way ANOVA test using the IBM SPSS Statistics 24 tool was carried out to see the differences between the three series of the 2019 Election. In addition, this test was carried out to see which events had stronger information to the market.

Table 9. One-way Anova Abnormal Return

\begin{tabular}{lccccc}
\hline & $\begin{array}{c}\text { Sum of } \\
\text { Squares }\end{array}$ & Df & $\begin{array}{c}\text { Mean } \\
\text { Square }\end{array}$ & F & Sig. \\
\hline $\begin{array}{l}\text { Test of Homogeneity } \\
\text { of Variances }\end{array}$ & & & & &, 189 \\
Between Groups &, 000 & 2 &, 000 &, 000 & 1,000 \\
Within Groups &, 006 & 41 &, 000 & & \\
Total &, 006 & 43 & & & \\
\hline
\end{tabular}

Sources: Data processed, 2020

The table above shows the results of the One-way Anova test for the abnormal return of the three tested events. Previously, from this table, it can be seen that the abnormal returns of the three events have the same variance. This is evidenced by the significant value of the Test of Homogeneity of Variances greater than $5 \%$, which is equal to 0.189 . From the table, it can be seen that the significant p-value is 1,000 and is greater than $5 \%$. It can be concluded that there is no significant difference between the three events studied. Therefore, the hypothesis which states, "There is a difference in the average abnormal return in the three series of the 2019 General Election," is rejected. 
Table 10. One-way Anova of Trading Volume Activity

\begin{tabular}{lc|c|c|c|c}
\hline & Sum of Squares & Df & $\begin{array}{c}\text { Mean } \\
\text { Square }\end{array}$ & F & Sig. \\
\hline $\begin{array}{l}\text { Test of Homogeneity } \\
\text { of Variances }\end{array}$ & & & & &, 527 \\
Between Groups &, 000 & 2 &, 000 &, 617 &, 545 \\
Within Groups &, 000 & 41 &, 000 & & \\
Total &, 000 & 43 & & & \\
\hline
\end{tabular}

Sources: Data processed, 2020

The table above is the One-way Anova test results for trading volume activity of the three tested events. Previously, from this table, it can be seen that the trading volume activity of the three events has the same variance. This is evidenced by the significant value of the Test of Homogeneity of Variances greater than $5 \%$, which is 0.527 . From the table, it can be seen that the significant $p$-value is 0.545 and is greater than $5 \%$. It can be concluded that there is no significant difference between the three events studied. Therefore the hypothesis which states, "There is a difference in the average trading volume activity in the three series of the 2019 General Election" is rejected.

The series of events for the 2019 General Election, which are held simultaneously for the presidential and legislative elections, are a political event that is both macro and national in nature, which is expected to bring better changes than before. The 2019 General Election, with its various series, from pre-election to post-election, brings several issues and information that is accepted by the public. The market can respond to any of this information by showing an abnormal return around the study period. This information can be considered good if the abnormal return is positive, and the information is deemed to be bad with a negative abnormal return (Tandelilin, 2010). In addition, a market response can also be seen through trading volume activity (TVA) around the research period.

Based on the tests that have been carried out, that only the second event, namely the announcement of the 2019 general election results by the KPU, has a difference in the average abnormal return before and after its implementation. Thus, it can be concluded that only the second event was successful in showing a significant influence between the stock return variable and the events of the 2019 General Election series.

Although there are test results that do not differ significantly, if you look at the overall graph of the 2019 Election series studied, as a whole, it shows that from five days (d-5) to the third (d-3) and second (d-2) days before The main day shows a negative abnormal return. This is because investors are taking profit taking or seeking profit, and as a 
preventive action to find a safe point so that if the risk of stock prices continues to decline, it can be avoided.

Meanwhile, starting from $\mathrm{h}-3$ and $\mathrm{h}-2$, the abnormal return creeps up. This is because investors in the Islamic capital market seek to profit by buying shares at the lowest price and will sell them when conditions are considered to be maximal. This has resulted in a decrease in pol. 3, No. 2, December 2020, abnormal returns on the day before and on the day of the 2019 Election series. After investors receive information from these series, investors can assume that conditions have returned to stability and confidence for transactions in the capital market has strengthened again, resulting in an increase in $\mathrm{h}+2$ or $\mathrm{h}+3$ thereafter and fluctuates back until the end of the observation period.

The KPU's announcement of the results of the 2019 General Election had a more favorable response from the market because at that time investors had been given certainty that the presidential candidate pair was officially elected. Even though the results of quick counts have shown the victory of the same candidate pair, these results are still considered to be different from the official calculation and also the condition of the fragmentation of information in accordance with the claims of each camp which makes the information after the election is less convincing. In addition, the announcement of the results of the election lawsuit by the Constitutional Court is also considered not to really affect the market, because the market already has confidence and certainty with the previous KPU's announcement.

The movement of stock trading and the rate of return in the capital market can not only be calculated by a particular event. More than that, investors also look at other macroeconomic factors such as the inflation rate, the rupiah exchange rate, economic growth, interest rates, and so on. The fluctuation of abnormal returns and trading volume activity in each series of the 2019 Election indicates that there are a response and action taken by investors in the Islamic capital market to the information obtained regarding the 2019 Election series. Thus, it can be said that this research supports the theory of market efficiency (efficient market hypothesis) in the form of a semi-strong form (half strong information). This form describes a market where the prices of securities fully reflect all published information, and all investors can enjoy the abnormal return from the information obtained.

\section{CONCLUSION}

Based on the t-test on the abnormal return of the three series of the 2019 Election, only the second event, namely the announcement of the 2019 general election results by the KPU, has a difference in the average abnormal return before and after its implementation. Thus, it can be concluded that only the second event was successful in showing a significant influence between the stock return variable 
and the 2019 General Election series events. Meanwhile, the trading volume of the three series of the 2019 General Election, based on tests that have been conducted, all events in the 2019 General Election series have a difference in the average trading volume before and after its implementation. Thus, it can be concluded that the whole event succeeded in showing a significant influence between the variable volume of stock trading activities and the events of the 2019 General Election in the Islamic capital market. This research provide and evidence that there is an information content that has valuable impact for the investor in the political events, especially General Election. In fact, Islamic capital market also has strong relationship with the whole issue in politic. Hence, the paper recommend for the policy-makers to prepare such a policy in mitigating the political risk that will happen during the general election. For the invstors, they must concern on the fluctuation of capital market in the time of general election to ensure that their portfolio genarate a rational return.

\section{REFERENCES}

Ardiansyah, Misnen dan Abdul Qoyum. (2011). "Testing The SemiStrong Form Efficiency Of Islamic Capital Market With Response To Information Content Of Dividend Announcement- A Study In Jakarta Islamic Index" dalam International Conference On Management (ICM).

Bailey, W., dan Chung Y.P. (1995). Exchange Rate Fluctuations, Political Risk, and Stock Returns: Some Evidence From an Emerging Market. Journal of Financial and Quantitatives Analysis. Vol. 30, No. 4.

Bloomberg News oleh Harry Suhartono. (2019). "How Investors Can Prepare for a Surprise Indonesia Election Outcome" dalam https:// www.bloomberg.com/news/articles/2019-04-08/how-investors-canprepare-for-a-surprise-indonesia-poll-outcome dirilis pada 9 April 04.00 WIB.

Bowman, R. (1983). "Understanding and Conducting Event Studies" dalam Journal of Business Finance \& Accounting.

CCN Indonesia. (2019). "Moody's Sebut Hasil Hitung Cepat Pilpres Dukung Investasi" dalam

https://m.cnnindonesia.com/ekonomi/moodys-sebut-hasil-hitungcepat-pilpres-dukung-investasi dirilis pada 18 April diakses pada 31 Oktober 2019.

Darmadji, Tjiptono dan Hendy M Fakhruddin. (2001). Pasar Modal di Indonesia: Pendekatan Tanya Jawab. Jakarta: Salemba Empat.

Fama, Eugene F. (1970)." Efficient Capital Market: A Review of Theory and Empirical Work". Journal of Finance, Desember Vol. XLVI No.5.

Husnan, Suad. (2005). Dasar-Dasar Teori Portofolio dan Analisis Sekuritas. Yogyakarta: UPPAMP-YKPN. 
Ipotnews oleh Marjudin. (2019). "Usai Pengumuman KPU, Laju Pertumbuhan Industri dan Investasi Diyakini Membaik" dalam https://www.indopremier.com/ipotnews/Usai-Pengumuman-KPLaju-Pertumbuhan-Industri-dan-Investasi-Diyakini-Membaik dirilis pada 21 Mei diakses pada 31 Oktober 2019.

Vol. 3. №. 2. December 2020, tentono, Jogiyanto. (2010). Studi Peristiwa: Menguji Reaksi Pasar Modal pp. 105-124, ISSN p:2622-4755 Akibat Suatu Peristiwa. Yogyakarta: BPFE. . (2010). Teori Portofolio dan Analisis Investasi Edisi 3. Yogyakarta: BPFE.

Kontan.co.id oleh Yusuf Imam Santoso. (2019). "Begini Prospek Investasi Pasca Putusan MK" dalam https://amp.kontan.co.id/news/beginiprospek-investasi-pasca-putusan-mk dirilis pada 27 Juni diakses pada 31 Oktober 2019.

Manurung, Adler Haymans dan Cahyanti Ira K. (2005). "Pengaruh Peristiwa Politik (Pengumuman Hasil Pemilu Legislatif, Pengumuman Hasil Pemilihan Presiden, Pengumuman Susunan Kabinet, Reshuffle Kabinet) Terhadap Sektor-Sektor Industri di Bursa Efek Jakarta" dalam Jurnal Perbankan.

Napitupulu, Veronica dan Syahyunan. (2012). "Pengaruh Return Saham, Volume Perdagangan dan Volatilitas Harga saham terhadap Bid- Ask Spread pada perusahaan yang melakukan stock split di Bursa Efek Indonesia". Journal.

Otoritas Jasa Keuangan. (2016). Pasar Modal. Seri Literasi Keuangan Perguruan Tinggi. Jakarta: Bidang Edukasi dan Perlindungan Konsumen, Otoritas Jasa Keuangan.

Qoyum, A., Al Hashfi, R. U., Zusryn, A. S., Kusuma, H., \& Qizam, I. (2020). Does an islamic-sri portfolio really matter? Empirical application of valuation models in indonesia. Borsa Istanbul Review. https://doi.org/10.1016/j.bir.2020.08.002

Renneboog, L., Ter Horst, J., \& Zhang, C. (2008). Socially responsible investments: Institutional aspects, performance, and investor behavior. Journal of Banking \& Finance, 32(9), 1723-1742. https:// doi.org/10.1016/j.jbankfin.2007.12.039

Revelli, C. (2017). Socially responsible investing (SRI): From mainstream to margin? Research in International Business and Finance, 39, 711-717. https://doi.org/10.1016/j.ribaf.2015.11.003

Rizaldy, M. R., \& Ahmed, H. (2019). Islamic legal methodologies and Shariah screening standards: Application in the Indonesian stock market. Thunderbird International Business Review, 61(5), 793-805. https://doi.org/10.1002/tie.22042

Sadeghi, M. (2008). Financial Performance of Shariah-Compliant Investment: Evidence from Malaysian Stock Market. 20, 12. 
Salma Sairally, B. (2013). Evaluating the corporate social performance of Islamic financial institutions: An empirical study. International IHTIFAZ - JIEFB Journal of Islamic and Middle Eastern Finance and Management, 6(3), 238-260. https://doi.org/10.1108/IMEFM-02-2013-0026

Setyowati, Hasanah dan Riyanti Ningsih. (2016). " Pengaruh Faktor Fundamental, Risiko Sistematis dan Ekonomi Makro Terhadap Return Saham Syariah yang Tergabung di Jakarta Islamic Index (JII) pada Periode 2010 - 2014". Jurnal Kajian Bisnis Vol. 24, NO. 1, 54 - 70.

Suryawijaya, Asri Marwan, dan Setiawan Faizal Arief. (1998). "Reaksi Pasar Modal Indonesia Terhadap Peristiwa Politik Dalam Negeri (Event Study pada Peristiwa 27 Juli 1996)", dalam Kelola No. 18.

Tecualu, Melitina dan Megge Rianny. (2009). "Reaksi Pasar Modal Indonesia Terhadap Peristiwa BOM Kuningan 2009" dalam IImiah Manajemen dan Bisnis Vol 10 No10.

Tanjung, H., \& Martua Siregar, T. A. (2018). Analisis Votalitas Saham di Jakarta Islamic Index (JII) periode Januari 2015-Januari 2018. Ihtifaz: Journal of Islamic Economics, Finance, and Banking, 1(1), 147. https:// doi.org/10.12928/ijiefb.v1i1.270

Widodo, S. (2017). Analisis Pengaruh Rasio Aktivitas, Rasio Profitabilitas, Dan Rasio Pasar, Terhadap Return Saham Syariah Dalam Kelompok Jakarta Islamic Index (Jii) Tahun 2003 - 2005. In Universitas Diponegoro. http://eprints.undip.ac.id/18617/1/SANIMAN_WIDODO.pdf
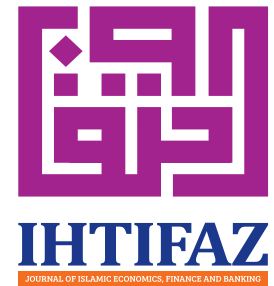

UNIVERSITAS AHMAD DAHLAN

Kampus 4 J. Ringroad Selatan, Tamanan Banguntapan, Bantul e-mail : ihtifaz@uad.ac.id 